\title{
Carbon Nanostructures as Low Cost Counter Electrode for Dye-Sensitized Solar Cells
}

\author{
Qiquan Qiao \\ South Dakota State University \\ United States
}

\section{Introduction}

In the last two decades, dye sensitized solar cells (DSSCs) have gained extensive attention as a low cost alternative to conventional Si solar cells (Oregan \& Gratzel 1991; Fan et al. 2008; Xie et al. 2009; Alibabaei et al. 2010; Gajjela et al. 2010; Xie et al. 2010; Yum et al. 2010). A typical DSSC is made of a $\mathrm{TiO}_{2}$ photoanode and a $\mathrm{Pt}$ counter electrode separated by an electrolyte comprising an iodide/triiodide $\left(\mathrm{I}^{-} / \mathrm{I}^{-}\right)$redox couple. The photoanode is usually prepared from $\mathrm{TiO}_{2}$ nanoparticles on a transparent conducting oxide (TCO), while the counter electrode is a thin layer of $\mathrm{Pt}$ deposited on another TCO substrate. The dye molecules are adsorbed onto $\mathrm{TiO}_{2}$ surface. When exposed to sunlight, photoelectrons are generated and injected into the photoanode. Afterward, the electrons travel to counter electrode through an outside load. The oxidized dye molecules then retake electrons from $\mathrm{I}^{-}$ ions and oxidize $\mathrm{I}^{-}$into $\mathrm{I}^{3^{-}}$. Meanwhile, the $\mathrm{I}^{3^{-}}$is reduced into $\mathrm{I}^{-}$by taking electrons from counter electrode. Pt counter electrode has been extensively used as an efficient electrocatalyst for reduction of $\mathrm{I}^{3^{-}}$ions in DSSCs (Gratzel 2003; Sun et al. 2010). However, Pt is an expensive metal and can also be corroded by $\mathrm{I}^{-} / \mathrm{I}^{3^{-}}$redox couple (Kay \& Gratzel 1996). Recently, various carbonaceous materials including graphite, carbon black, and carbon nanotubes have been studied as a low cost replacement for $\mathrm{Pt}$ as an electrocatalyst for reduction of $\mathrm{I}^{3^{-}}$ions (Kay \& Gratzel 1996; Burnside et al. 2000; Imoto et al. 2003; Imoto et al. 2003; Suzuki et al. 2003; Murakami et al. 2006; Ramasamy et al. 2007; Fan et al. 2008; Hinsch et al. 2008; Joshi et al. 2009; Lee et al. 2009; Skupien et al. 2009; Calandra et al. 2010). The carbonaceous materials are plentiful, inexpensive, and also exhibit high resistivity to corrosion (Ramasamy et al. 2007). Replacement of Pt with carbon-based materials can also speed up DSSC commercialization (Burnside et al. 2000; Hinsch et al. 2008; Han et al. 2009; Skupien et al. 2009; Joshi et al. 2010).

In this chapter, we review some carbon nanostructures including carbon nanoparticles and electrospun carbon nanofibers that have been successfully used as a low cost alternative to $\mathrm{Pt}$ in DSSCs. The carbon nanoparticle- and carbon nanofiber-based DSSCs showed comparable performance as that of Pt-based devices in terms of short circuit current density (Jsc) and open circuit voltage (Voc). Electrochemical impedance spectroscopy (EIS) measurements indicated that the carbon nanoparticle and carbon nanofiber counter electrodes showed lower charge transfer resistance $\left(R_{\mathrm{ct}}\right)$, suggesting that carbon nanoparticle and carbon nanofiber counter electrodes are an efficient electrocatalyst for DSSCs. In addition, the series resistance of carbon-based counter electrodes was found to be a little 
higher than that of Pt cells, leading to a slightly lower FF. Herein, we will first introduce the preparation and characterization of carbon nanoparticle and carbon nanofiber counter electrodes. Then, the fabrication of DSSC devices with these carbon-based counter electrodes will be described and compared with Pt-based cells. The use of carbon nanoparticle and carbon nanofiber counter electrodes has a great potential to make low cost DSSC technology one step closer to commercialization.

\section{Carbon/ $/ \mathrm{TiO}_{2}$ composite as counter electrode}

Low cost carbon/ $\mathrm{TiO}_{2}$ composite was used as an alternative to platinum as a counterelectrode catalyst for tri-iodide reduction. In the carbon/ $\mathrm{TiO}_{2}$ composite, carbon is nanoparticles and acts as an electrocatalyst for triiodide reduction, while the $\mathrm{TiO}_{2}$ functions as a binder. The carbon/ $\mathrm{TiO}_{2}$ composite can be deposited by spin coating or doctor blading onto a fluorine-doped Tin Dioxide (FTO).

\subsection{Preparation of carbon/ $/ \mathrm{TiO}_{2}$}

Carbon nanoparticles (Sigma-Aldrich) have a particle size $<50 \mathrm{~nm}$ and a surface area $>100$ $\mathrm{m}^{2} / \mathrm{g}$. The $\mathrm{TiO}_{2}$ paste was prepared by dispersing $\mathrm{TiO}_{2}$ nanoparticles (P25 Degussa, average size of $25 \mathrm{~nm}$ ) into water. The carbon/ $\mathrm{TiO}_{2}$ composite was made by mixing $650 \mathrm{mg}$ carbon nanoparticles with $1 \mathrm{ml} \mathrm{TiO}$ colloid paste at a concentration of $20 \mathrm{wt} \%$. Then $2 \mathrm{ml}$ deionized (DI) water was added, followed by grinding and sonication. $1 \mathrm{ml}$ Triton X-100 was added during grinding. The final paste was then spin coated onto a FTO glasses to form the counter electrode, followed by sintering at $250^{\circ} \mathrm{C}$ for an hour.

The scanning electron microscopy (SEM) images of carbon/ $\mathrm{TiO}_{2}$ composite and pure $\mathrm{TiO}_{2}$ nanoparticle films are shown in Figure $1 \mathrm{a}$ and $\mathrm{b}$, respectively. It can be seen that the carbon/ $\mathrm{TiO}_{2}$ composite counter-electrode film is highly porous with a large surface area, which can function effectively for tri-iodide reduction. The pore size ranges from $20 \mathrm{~nm}$ to $200 \mathrm{~nm}$ throughout the film, which is large enough for $\mathrm{I}^{-} / \mathrm{I}_{3}{ }^{-}$ions that are only a few angstroms to diffuse into the pores and get reduced at the carbon nanoparticle surface(Ramasamy et al. 2007). The particle size in carbon/ $\mathrm{TiO}_{2}$ composite film (Figure 1a) is apparently larger than those in pure $\mathrm{TiO}_{2}$ nanoparticle film (Figure 1b). This suggests that the carbon nanoparticle dominates in carbon/ $\mathrm{TiO}_{2}$ mixture and effectively serves as a catalyst for tri-iodide reduction. A cross-section SEM image (Figure 1c) shows that the carbon/ $\mathrm{TiO}_{2}$ composite counter electrode has a thickness of about $11.2 \mathrm{um}$.

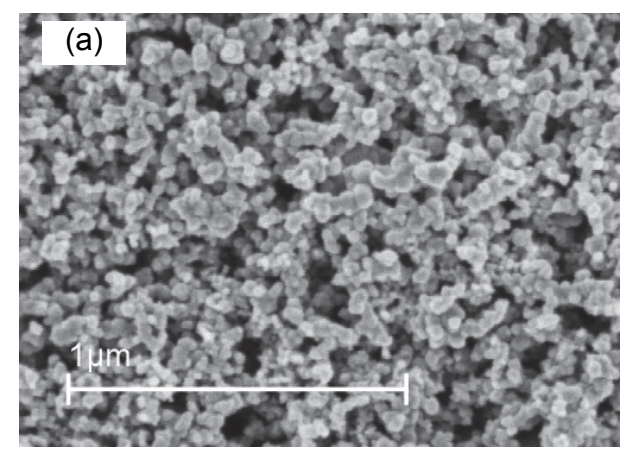



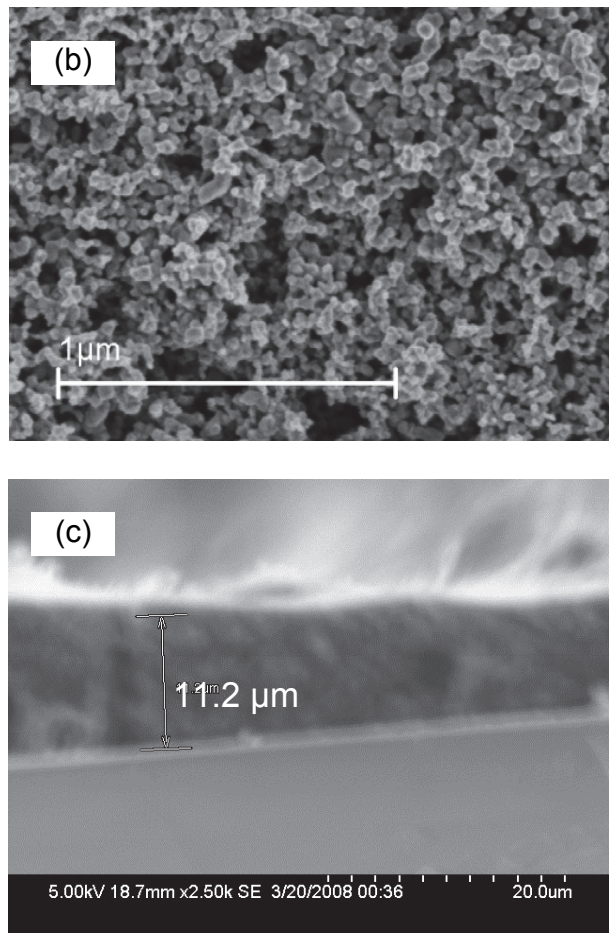

Fig. 1. SEM images of (a) 11.2 um thick carbon/ $\mathrm{TiO}_{2}$ composite layer and (b) pure $\mathrm{TiO}_{2}$ nanoparticle layer on a FTO substrate. Cross section SEM image of (c) the carbon/ $/ \mathrm{TiO}_{2}$ composite layer. Reproduced with permission from Ref (Joshi et al. 2009).

\subsection{Calculation of series resistance, left justified}

Ramasamy et al. measured the charge transfer resistance $\left(R_{\mathrm{ct}}\right)$ of carbon electrode via electrochemical impedance spectroscopy (EIS) and found that $R_{\mathrm{ct}}$ was $0.74 \Omega \mathrm{cm}^{-2}$, two times less than that of the screen printed Pt (Ramasamy et al. 2007). Since the thickness of carbonbased counter electrode is tens of micrometers that are much higher than $\mathrm{Pt}$ at a thickness of about tens of nanometers, the internal series resistance $\left(R_{\mathrm{se}}\right)$ of carbon-based DSSCs are found to be higher (Ramasamy et al. 2007; Joshi et al. 2009). The lower $R_{\text {ct }}$ counterbalances the higher $\mathrm{R}_{\mathrm{se}}$ of carbon-based device. The series resistance of carbon/ $\mathrm{TiO}_{2}$ composite based DSSCs was also studied and compared with that of platinum-based devices under multiple light intensities.

Current density $\left(\mathrm{J}_{\mathrm{sc}}\right)$ through the series resistance is as below (Matsubara et al. 2005):

$$
J=J_{P H}-\frac{V-I R_{s}}{A R_{s h}}-J_{0}\left(\exp \left[q\left(V-J A \quad R_{s}\right) / n k T\right]-1\right)
$$

This equation can be modified as:

$$
J_{P H}-J=\frac{V-J A R_{s}}{A R_{s h}}+J_{0}\left(\exp \left[q\left(\begin{array}{ll}
V-J A & R_{s}
\end{array}\right) / n k T\right]-1\right)
$$



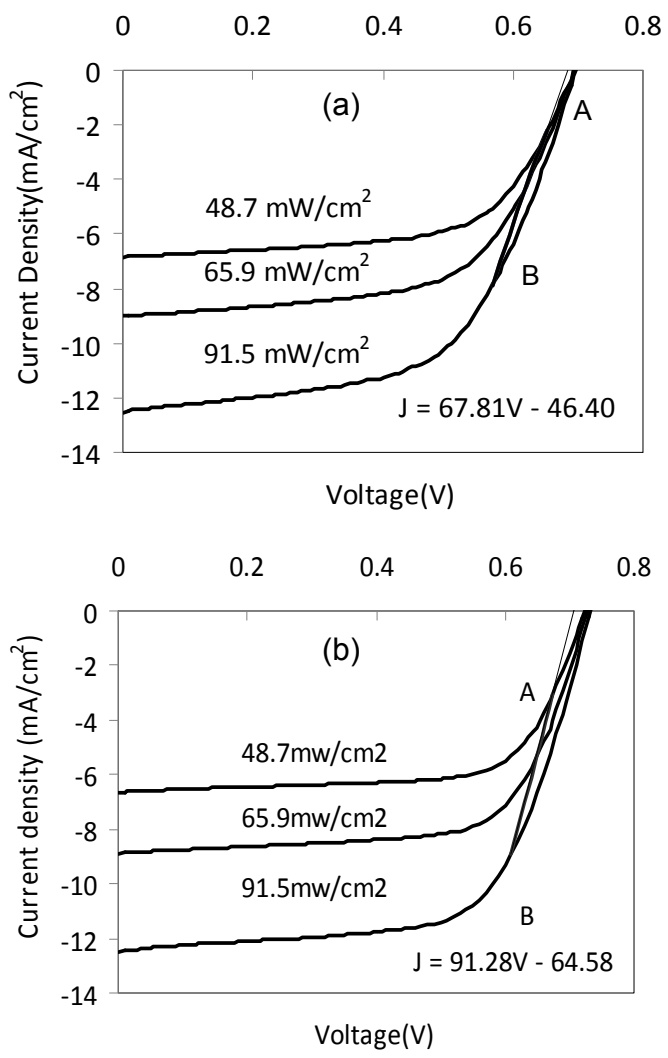

Fig. 2. J-V curves of DSSC devices at different light intensity from (a) carbon/ $\mathrm{TiO}_{2}$ composite and (b) Pt counter electrode. Reproduced with permission from Ref (Joshi et al. 2009).

When we plot current density-voltage $(\mathrm{J}-\mathrm{V})$ curves at multiple light intensities and select the points of $(\mathrm{J}, \mathrm{V})$ which satisfy the following condition:

$$
J_{P H}-J=\Delta J=\text { constant }
$$

The points should lie in the straight line and follow:

$$
J=V / R s A+\text { constant }
$$

Thus, the series resistance can be determined from the slope of a straight line. The current density-voltage $(\mathrm{J}-\mathrm{V})$ curves at different light intensities of the carbon/ $\mathrm{TiO}_{2}$-based and $\mathrm{Pt}$ based DSSC devices are shown in Figure 2a and b, respectively.

\subsection{Device performance of carbon/ $\mathrm{TiO}_{2}$ composite counter electrode}

The active area of carbon/ $\mathrm{TiO}_{2}$ composite is $0.20 \mathrm{~cm}^{2}$, while that of $\mathrm{Pt}$ devices is $0.24 \mathrm{~cm}^{2}$. The slope of the straight line $\mathrm{AB}$ in carbon/ $\mathrm{TiO}_{2}$ composite devices is $67.81 \mathrm{~mA} /\left(\mathrm{cm}^{2} \mathrm{~V}\right)$, 
with a reciprocal of $14.75 \Omega \mathrm{cm}^{2}$. The slope of the straight line AB in Pt-based devices is 91.28 $\mathrm{mA} /\left(\mathrm{cm}^{2} \mathrm{~V}\right)$ and its reciprocal is $11.37 \Omega \mathrm{cm}^{2}$. Apparently the series resistance of carbon/ $\mathrm{TiO}_{2}$ devices is larger than that of $\mathrm{Pt}$ devices. This can be possibly attributed to the much thicker layer and larger resistivity of carbon $/ \mathrm{TiO}_{2}$ counter electrode than those of $\mathrm{Pt}$ (Imoto et al. 2003). However, the carbon $/ \mathrm{TiO}_{2}$ counter electrode has its own advantage that is the large surface area. This results in a lower $R_{c t}$, which was found to be less than half of that in the Pt counter electrode (Ramasamy et al. 2007). The lower $R_{c t}$ can compensate the effects of higher series resistance.

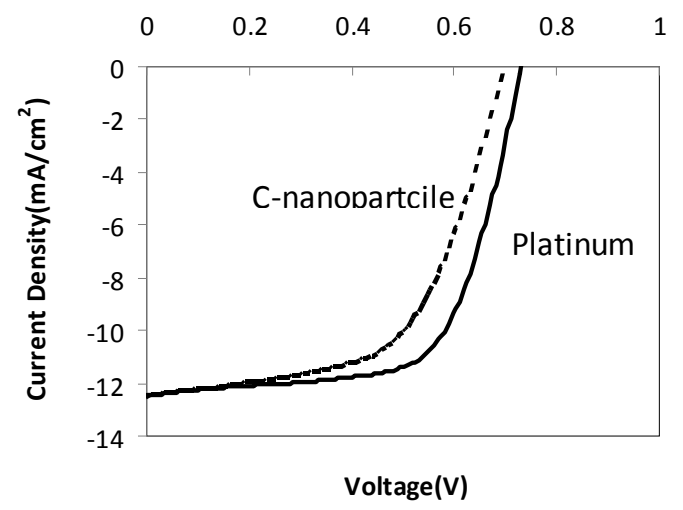

Fig. 3. J- $V$ curves of DSSC devices with carbon $/ \mathrm{TiO}_{2}$ composite (dash line) and $\mathrm{Pt}$ (solid line) counter electrode under AM 1.5 illumination (light intensity: $91.5 \mathrm{~mW} / \mathrm{cm}^{2}$ ). Reproduced with permission from Ref (Joshi et al. 2009).

Figure 3 shows a comparison of $\mathrm{J}-\mathrm{V}$ curves from carbon/ $\mathrm{TiO}_{2}$ and $\mathrm{Pt}$ devices under an $\mathrm{AM}$ 1.5 solar simulator at an intensity of $\sim 91.5 \mathrm{~mW} / \mathrm{cm}^{2}$. DSSCs with carbon/ $\mathrm{TiO}_{2}$ counter electrode achieve an efficiency of $5.5 \%$, which is comparable to $6.4 \%$ of Pt counter electrode devices. The photovoltaic parameters in terms of short circuit current density (Jsc), open circuit voltage (Voc), fill factor (FF) and efficiency ( $\eta$ ) are listed in Table 1. The FF of carbon/ $\mathrm{TiO}_{2}$ devices was found to be slightly lower than Pt devices. This may be attributed to higher series resistance $\left(14.75 \Omega \mathrm{cm}^{2}\right)$ in the former compared to that $\left(11.37 \Omega \mathrm{cm}^{2}\right)$ in the latter. Ramasamy et al. studied the robustness of carbon-based DSSCs and their results showed that carbon-based cells have a comparable stability as Pt-based devices (Ramasamy et al. 2007).

\begin{tabular}{llllll}
\hline Counter electrodes & Jsc $\left(\mathbf{m A} / \mathbf{c m}^{2}\right)$ & Voc $(\mathbf{V})$ & FF & $\mathbf{\eta}$ & $\begin{array}{l}\text { Rs } \\
(\mathbf{\Omega})\end{array}$ \\
\hline $\begin{array}{l}\text { carbon } / \mathrm{TiO}_{2} \\
\text { composite }\end{array}$ & 12.53 & 0.70 & 0.57 & $5.5 \%$ & $14.75 \Omega \mathrm{cm}^{2}$ \\
\hline \begin{tabular}{l} 
Platinum \\
\hline
\end{tabular} & 12.48 & 0.73 & 0.65 & $6.4 \%$ & $11.37 \Omega \mathrm{cm}^{2}$ \\
\hline
\end{tabular}

Table 1. DSSC device parameters from carbon/ $\mathrm{TiO}_{2}$ composite and Pt counter electrode. Reproduced with permission from Ref (Joshi et al. 2009). 


\section{Carbon nanofibers as counter electrode}

Carbon nanofibers prepared by electrospinning were also explored as low cost alternative to $\mathrm{Pt}$ for triiodide reduction catalyst in DSSCs. The carbon nanofiber counter electrode was characterized by EIS and cyclic voltammetry measurements. The carbon nanofiber counter electrode exhibited low charge transfer resistance $\left(R_{\mathrm{ct}}\right)$, small constant phase element $(\mathrm{CPE})$ exponent $(\beta)$, large capacitance $(C)$, and fast reaction rates for triiodide reduction.

\subsection{Preparation of carbon nanofiber counter electrode}

The carbon nanofiber paste was made by mixing $0.1 \mathrm{~g}$ ECNs with $19.6 \mathrm{~g}$ polyoxyethylene(12) tridecyl ether (POETE) in a similar method reported by others (Mei \& Ouyang 2009). The mixture was then grinded, sonicated, and centrifuged at a spin speed of 10,000 rpm to uniformly disperse the ECNs in POETE. Any extra POETE that floated on top of the mixture after the centrifuge was removed via a pipette. Afterwards, the counter electrode was made by doctor-blading the mixture onto FTO $(\sim 8 \Omega / \square$ and $\sim 400 \mathrm{~nm})$, followed by sintering at $200^{\circ} \mathrm{C}$ for $15 \mathrm{~min}$ and then at $475^{\circ} \mathrm{C}$ for $10 \mathrm{~min}$. Figure 4 shows SEM and transmission electron microscope (TEM) images of the original carbon nanofibers prepared by electrospinning and the carbon nanofiber counter electrode on FTO deposited by doctor blading. In the original electrospun carbon nanofiber samples, the ECNs were relatively uniform in diameter with an average value of $\sim 250 \mathrm{~nm}$ (Figure 4a). The TEM image in Figure $4 \mathrm{~b}$ shows that the structure of ECNs was primarily turbostratic instead of graphitic; i.e., tiny graphite crystallites with sizes of a few nanometers were embedded in amorphous carbonaceous matrix. The nanofiber sheet did not show evidence of microscopically identifiable beads or beaded-nanofibers. The BET surface area of the carbon nanofiber sheet was measured to be $\sim 100 \mathrm{~m}^{2} / \mathrm{g}$ via a Micromeritics ASAP 2010 surface area analyzer using $\mathrm{N}_{2}$ adsorption at $77 \mathrm{~K}$.
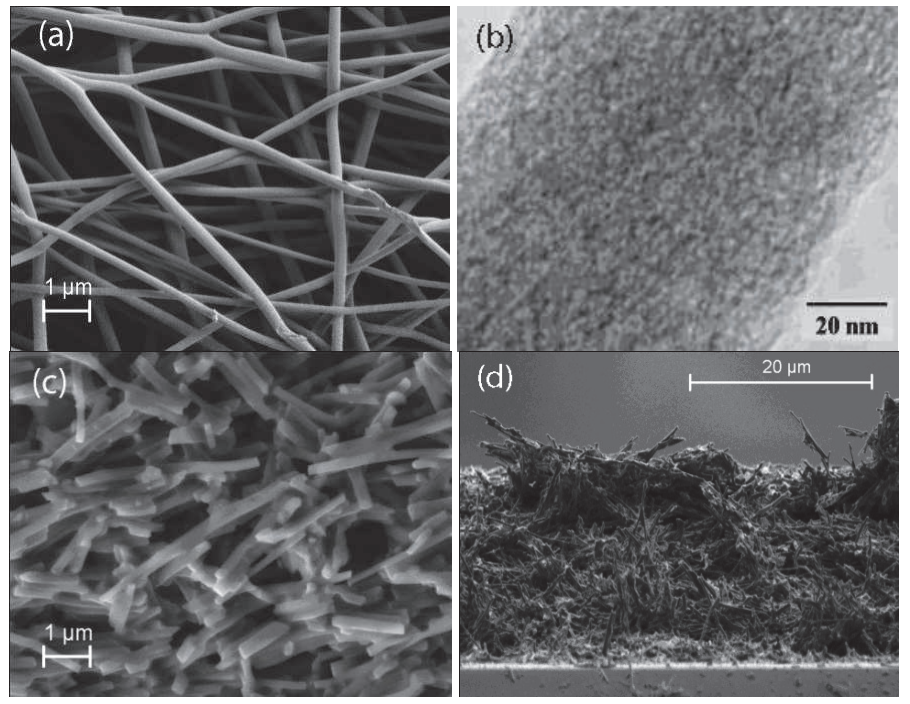

Fig. 4. (a) SEM image of electrospun carbon nanofiber film; (b) TEM image of a typical single carbon nanofiber; SEM image of (c) top-view and (d) cross-section of carbon nanofiber counter electrode. Reprinted with permission from \{Joshi et al. 2010\}. Copyright $\{2010\}$ American Chemical Society. 
Because it was difficult to attach the original carbon nanofiber sheet onto FTO, we added POETE into the carbon nanofiber, followed by grinding and sonication. As shown in Figure $4 \mathrm{c}$, the nanofibers that were originally tens of microns long were broken into submicrons to microns after grinding and sonication. The conductivity of original electrospun carbon nanofibers (Figure 4a) is $\sim 1538 \mathrm{Sm}^{-1}$, but decreased to $\sim 164 \mathrm{Sm}^{-1}$ after converted to the counter electrode as shown in Figure 4c. This can possibly be attributed to the much smaller lengths of the carbon nanofibers that reduced conduction network. Also, the POETE was burned away at high temperature, causing additional voids between carbon nanofibers. However the smaller length of carbon nanofibers may increase the surface area of the counter electrode, which can be seen by comparing Figure 4a with Figure 4c. The thickness of counter electrode was about of $24 \mu \mathrm{m}$ (Figure 4d), which is much higher than that of carbon nanoparticle counter electrodes. The effects of carbon nanoparticle counter electrode thickness on DSSC parameters including Jsc, Voc, FF and cell efficiency ( $\eta$ ) was studied by others (Murakami et al. 2006). They found that the thickness mainly affects FF and the optimal thickness was $\sim 14.5 \mu \mathrm{m}$ for carbon nanoparticle counter electrode. A thickness of $\sim 11.2 \mu \mathrm{m}$ was used in a carbon nanoparticle counter electrode DSSC device (Joshi et al. 2009). However, Ramasamy et al. prepared a carbon nanoparticle counter electrode with a larger thickness of $\sim 20 \mu \mathrm{m}$ (Ramasamy et al. 2007). Here, the thickness of carbon nanofiber counter electrode was higher than that of typical carbon nanoparticle counter electrode. As shown in Figure 4c, the shorter nanofibers are loosely packed with large voids and this can lead to smaller surface area than that of carbon nanoparticle counter electrode. A higher thickness was used to make the carbon nanofiber counter electrode to ensure a significant surface area.

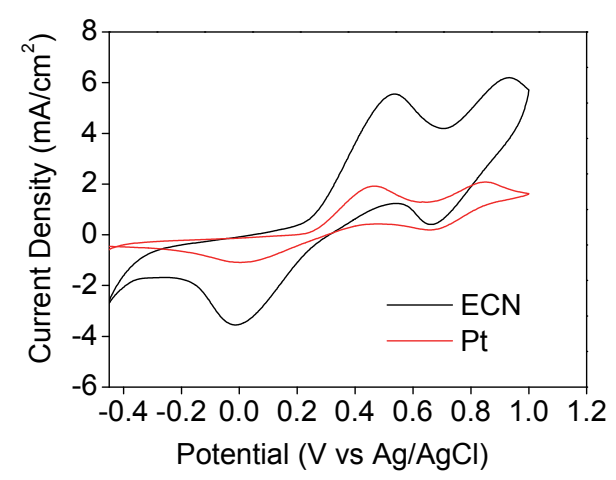

Fig. 5. Cyclic voltammograms of carbon nanofiber (black) and $\mathrm{Pt}$ (red) counter electrode. The measurement was performed in an acetonitrile solution comprising $10 \mathrm{mM} \mathrm{LiI}$ and $0.5 \mathrm{mM} \mathrm{I}_{2} .0 .1 \mathrm{M}$ tetra- $n$-butylammonium tetrafluoroborate was used as supporting electrolyte. $\mathrm{Ag} / \mathrm{AgCl}$ was used as reference electrode. The thickness of carbon nanofiber and Pt counter electrode is $\sim 24 \mu \mathrm{m}$ and $\sim 40 \mathrm{~nm}$, respectively. Reprinted with permission from \{Joshi et al. 2010\}. Copyright $\{2010\}$ American Chemical Society.

\subsection{Characterization of carbon nanofiber counter electrode}

Cyclic voltammograms (Figure 5) of the carbon nanofiber and $\mathrm{Pt}$ counter electrode were performed in an acetonitrile solution that comprises $10 \mathrm{mM} \mathrm{LiI}$ and $0.5 \mathrm{mM} \mathrm{I}_{2}$ using $0.1 \mathrm{M}$ 
tetra- $n$-butylammonium tetrafluoroborate as the supporting electrolyte. In the cyclic voltammetry $(\mathrm{CV})$ measurements, $\mathrm{Pt}$ wire was used as counter electrode, $\mathrm{Ag} / \mathrm{AgCl}$ as reference electrode, and a carbon nanofiber or Pt coated FTO as working electrode. Two pairs of oxidation and reduction peaks were found that are similar to those in the $\mathrm{Pt}$ electrodes. The oxidation and reduction pair on the left was from the redox reaction of $I_{3}^{-}+2 e^{-}=3 I^{-}$, while that on the right was attributed to the redox reaction of $3 I_{2}+2 e^{-}=2 I_{3}^{-}$ (Sun et al. ; Huang et al. 2007). The right pair from the carbon nanofiber sample exhibited a larger oxidation current density, but a smaller reduction current density than those of $\mathrm{Pt}$ electrode. This pair that was assigned to $3 I_{2}+2 e^{-}=2 I_{3}^{-}$had little effect on DSSC performance (Mei et al. 2010). The left pair of carbon nanofiber counter electrode showed both a larger oxidation and reduction current density than those of the Pt electrodes. This pair that was assigned to $I_{3}^{-}+2 e^{-}=3 I^{-}$directly affected DSC performance, indicating a fast rate of triiodide reduction.

The catalytic properties of counter electrode are usually characterized by EIS (Papageorgiou et al. 1997; Hauch \& Georg 2001). In order to eliminate the effects of $\mathrm{TiO}_{2}$ photoanode, a symmetrical carbon nanofiber - carbon nanofiber and Pt-Pt cells were fabricated for EIS study. These cells were prepared by assembling two identical carbon nanofiber (or Pt) electrodes face to face that were separated with an electrolyte of $\mathrm{I}^{-} / \mathrm{I}_{3}{ }^{-}$redox couple. The EIS characterization was performed using an Ametek VERSASTAT3-200 Potentiostat equipped with frequency analysis module (FDA). The amplitude of AC signal was $10 \mathrm{mV}$ with a frequency range of 0.1 $10^{5} \mathrm{~Hz}$. The Nyquist plots of the symmetrical carbon nanofiber - carbon nanofiber and $\mathrm{Pt}-\mathrm{Pt}$ cells are shown in Figure 6 . Figure $6 \mathrm{~b}$ shows the equivalent circuit that was used to fit impedance spectra. The equivalent circuit included charge transfer resistance $\left(R_{c t}\right)$ at the carbon nanofiber or Pt electrode/electrolyte interface, constant phase element (CPE), series resistance $\left(R_{s}\right)$ and Warburg impedance $\left(Z_{W}\right)$ (Murakami et al. 2006). The $R_{c t}$ at the electrode/electrolyte interface can be obtained from the high frequency semicircle, while the $\mathrm{ZW}$ of the $\mathrm{I}^{-} / \mathrm{I}_{3}{ }^{-}$redox couple in the electrolyte can be fitted from the low frequency arc (Wang et al. 2009; Jiang et al. 2010; Li et al. 2010; Mei et al. 2010). The fitted results from the Nyquist plots were summarized in Table 2 . The $R_{\text {ct }}$ of carbon nanofiber counter electrode was $0.7 \Omega \mathrm{cm}^{2}$, less than half of that $\left(1.9 \Omega \mathrm{cm}^{2}\right)$ of the Pt electrode, suggesting a sufficient electro-catalytic capability. The CPE represents the capacitance at the interface between the carbon nanofiber or $\mathrm{Pt}$ and electrolyte, which can be described as:

$$
Z_{C P E}=\frac{1}{Y_{0}}(j \omega)^{-\beta}
$$

in which $Y_{0}$ is the CPE parameter, $\omega$ the angular frequency, and $\beta$ the CPE exponent $(0<\beta<1)$, and. The $Y_{0}$ and $\beta$ are constant that is independent of frequency.

An ideal capacitance has a perfect semicircle where $\beta$ is equal to 1 . However, the porous films, leaky capacitor, surface roughness and non-uniform current distribution frequently cause a non-ideal capacitance that deviates $\beta$ value away from 1 (Hauch \& Georg 2001; Murakami et al. 2006). The fitted $\beta$ value of the carbon nanofiber counter electrode was 0.82 , smaller than that (0.95) of the Pt electrode. A lower $\beta$ value suggested a higher porosity in carbon nanofiber electrode than that of Pt electrode (Murakami et al. 2006). In previous study, a $\beta$ value of 0.81 was found in a highly porous carbon nanoparticle counter electrode (Murakami et al. 2006). Also, the capacitance (C) in carbon nanofiber counter electrode was larger than that of Pt electrode, suggesting a higher surface area in carbon nanofiber counter 
electrode. A larger capacitance (C) was also found in other nanostructured counter electrodes with high porosity (Murakami et al. 2006; Jiang et al. 2010). Unfortunately, the fitted series resistance $\left(R_{s}\right)$ of carbon nanofiber counter electrode was $5.12 \Omega \mathrm{cm}^{2}$, more than twice of that of $2 \Omega \mathrm{cm}^{2}$ for Pt electrode. This can be attributed to the higher thickness $(\sim 24 \mu \mathrm{m})$ of carbon nanofiber counter electrode. It was previously reported that thicker films increase $R_{s}$ in carbon nanoparticle counter electrodes (Murakami et al. 2006).

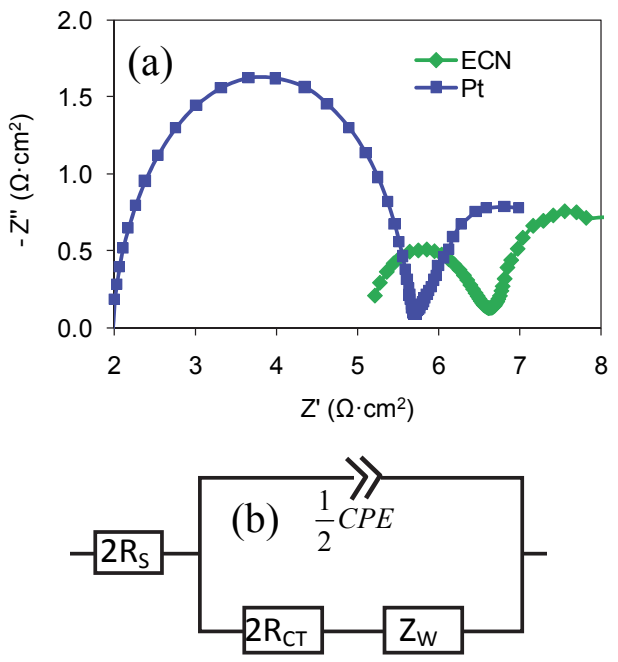

Fig. 6. (a) Nyquist plots of symmetrical carbon nanofiber-carbon nanofiber or Pt-Pt electrode cell; (b) equivalent circuit that was used to fitted the EIS results. Rs is series resistance at the counter electrode, $R_{c t}$ charge transfer resistance, $Z_{w}$ Nernst diffusion impedance and CPE constant phase element. Reprinted with permission from \{Joshi et al. 2010\}. Copyright $\{2010\}$ American Chemical Society.

\begin{tabular}{ccccc}
\hline $\begin{array}{c}\text { Counter } \\
\text { Electrode }\end{array}$ & $\mathbf{R}_{\mathbf{s}}\left(\mathbf{\Omega c m}^{2}\right)$ & $\mathbf{R}_{\mathrm{ct}}\left(\mathbf{\Omega} \mathbf{c m}^{2}\right)$ & $\begin{array}{c}\mathbf{C} \\
(\mathbf{F c m})\end{array}$ & $\boldsymbol{\beta}$ \\
\hline $\mathbf{E C N}$ & 5.12 & 0.70 & $5.6 \times 10^{5}$ & 0.82 \\
\hline $\mathbf{P t}$ & 2.00 & 1.89 & $2.0 \times 10^{5}$ & 0.95 \\
\hline
\end{tabular}

Table 2. Fitted results extracted from Nyquist plots of the respective symmetrical cells using carbon nanofiber or Pt as electrode. Reprinted with permission from \{Joshi et al. 2010\}.

Copyright $\{2010\}$ American Chemical Society.

\subsection{DSSC performance using carbon nanofiber counter electrode}

The $\mathrm{TiO}_{2}$ photoanode contained a blocking layer, a $\mathrm{TiCl}_{4}$-treated nanocrystalline $\mathrm{TiO}_{2}$ layer (Solaronix Ti-Nanoxide HT/SP) and a light scattering layer (Dyesol WER4-0). After sintering, the photoanode was soaked in a dye solution made of $0.5 \mathrm{mM}$ Ruthenizer 535bisTBA dye (Solaronix N-719) in acetonitrile/valeronitrile (1:1). The photoanode was then assembled with carbon nanofiber counter electrode using a thermoplastic sealant. The $\mathrm{I}^{-} / \mathrm{I}_{3}{ }^{-}$ electrolyte was finally injected into the cells. The reference DSSC devices with sputtered $\mathrm{Pt}$ layer $(40 \mathrm{~nm})$ as counter electrode were also fabricated for comparison in the same method. 

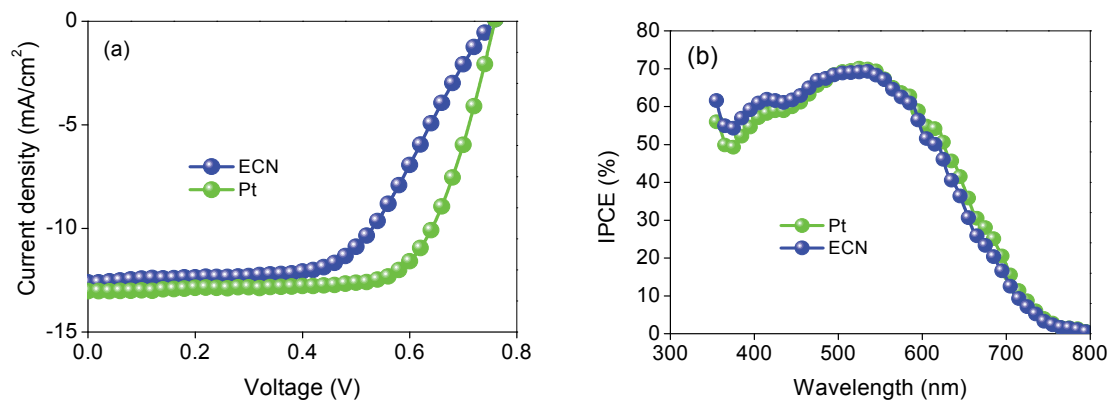

Fig. 7. (a) The J-V curves and (b) IPCE spectral action responses of carbon nanofiber (blue) and $\mathrm{Pt}$ (green) counter electrode DSSCs. Reprinted with permission from \{Joshi et al. 2010\}. Copyright $\{2010\}$ American Chemical Society.

The J-V curves of carbon nanofiber and Pt DSSCs are shown in Figure 7a, tested under AM 1.5 solar simulator illumination at $100 \mathrm{mWcm}^{-2}$. Table 3 summaries the device parameters from these two different types of cells. The carbon nanofiber counter electrode DSSCs

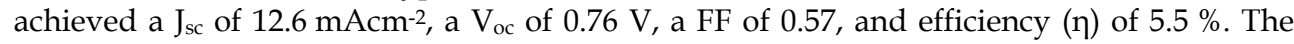
corresponding parameters $\left(\mathrm{J}_{\mathrm{sc}}, \mathrm{V}_{\mathrm{oc}}, \mathrm{FF}\right.$, and $\eta$ ) of Pt counter electrode DSSCs were $13.02 \mathrm{mAcm}^{-2}, 0.75 \mathrm{~V}, 0.71$, and $6.97 \%$, respectively. The $\mathrm{V}_{\mathrm{oc}} \mathrm{s}$ of carbon nanofiber and $\mathrm{Pt}$ counter electrode DSSCs were very close. The reverse saturation current $\left(\mathrm{J}_{0}\right)$ of carbon nanofiber counter electrode DSSCs was $4.47 \times 10^{-9} \mathrm{mAcm}^{-2}$, comparable to that of $3.58 \times 10^{-9}$ $\mathrm{mAcm}^{-2}$ for $\mathrm{Pt}$ counter electrode devices. $\mathrm{J}_{0}$ is usually regarded as a measure of recombination in solar cells. The comparable value to $\mathrm{J}_{0}$ suggested that carbon nanofiber counter electrode DSSCs had a comparable recombination as that of $\mathrm{Pt}$ counter electrode devices. It was previously reported that charge recombination at $\mathrm{FTO} / \mathrm{TiO}_{2}$ and $\mathrm{TiO}_{2}$ /electrolyte interfaces in DSSCs led to a $\mathrm{V}_{\text {oc }}$ loss (Huang et al. 1997; Gratzel 2000; Xia et al. 2007). The comparable Voc in carbon nanofiber and Pt counter electrode DSSCs further conformed that the former did not affect the charge recombination in the DSSCs. However, the $\mathrm{J}_{\mathrm{sc}}$ is lower in carbon nanofiber counter electrode DSSCs than that of $\mathrm{Pt}$ counter electrode DSSCs. Figure $7 \mathrm{~b}$ shows incident photon-to-current conversion efficiency (IPCE) spectral action responses of the two devices. It was found that IPCE of carbon nanofiber cells was slightly smaller than that of Pt devices in the 550-750 nm spectral range, consistent with the relatively lower $\mathrm{J}_{\mathrm{sc}}$. This was probably caused by that the Pt counter electrode can reflect unabsorbed light back to $\mathrm{TiO}_{2}$ photoanode for re-absorption by the dye (Fang et al. 2004; Lee et al. 2009; Wang et al. 2009). However, carbon nanofiber counter electrode cannot reflect such unabsorbed light. However, the reduction of $\mathrm{J}_{\mathrm{sc}}$ was insignificant and the real reason for lower $\eta$ in carbon nanofiber cells was the lower FF.

\begin{tabular}{ccccccc}
\hline $\begin{array}{c}\text { Counter } \\
\text { Electrode }\end{array}$ & $\begin{array}{c}\mathbf{J}_{\mathbf{s c}} \\
\left(\mathbf{m A c m} \mathbf{A c}^{-2}\right)\end{array}$ & $\begin{array}{c}\mathbf{V}_{\text {oc }} \\
(\mathbf{V})\end{array}$ & $\mathbf{F F}$ & $\begin{array}{c}\mathbf{n} \\
(\mathbf{\%})\end{array}$ & $\begin{array}{c}\mathbf{J}_{\mathbf{0}} \\
\left(\mathbf{m A c m} \mathbf{A c m}^{-2}\right)\end{array}$ & $\begin{array}{c}\mathbf{R}_{\text {Stot }} \\
\left(\mathbf{\Omega c m}^{2}\right)\end{array}$ \\
\hline Carbon Nanofiber & 12.60 & 0.76 & 0.57 & 5.5 & $4.47 \times 10^{-9}$ & 15.5 \\
\hline $\mathbf{P t}$ & 13.02 & 0.75 & 0.71 & 6.97 & $3.58 \times 10^{-9}$ & 4.8 \\
\hline
\end{tabular}

Table 3. The comparison of device parameters of carbon nanofiber and Pt counter electrode ( $\mathrm{R}_{\text {Stot: }}$ total series resistance, and $\mathrm{J}_{0}$ : reverse saturation current). Reprinted with permission from $\{$ Joshi et al. 2010\}. Copyright $\{2010\}$ American Chemical Society. 
The reduced FF may be caused by the increase of overall series resistance $\left(R_{\text {Stot }}\right)$ of the cells. The $R_{\text {Stot }}$ of carbon nanofiber counter electrode was $15.5 \Omega \mathrm{cm}^{2}$, much larger than that $\left(4.8 \Omega \mathrm{cm}^{2}\right)$ of $\mathrm{Pt}$ devices. Two possible reasons can explain the larger $\mathrm{R}_{\text {Stot }}$ in carbon nanofiber counter electrode DSSCs. First, the thickness of carbon nanofiber counter electrode $(\sim 24 \mu \mathrm{m})$ was much thicker than that $(40 \mathrm{~nm})$ of Pt electrode. Although the larger thickness provided a larger surface area for triiodide reduction with a reduced $R_{c t}$, it may increase electron transport length before reaching triiodide reduction sites and lead to higher internal series resistance (Murakami et al. 2006).
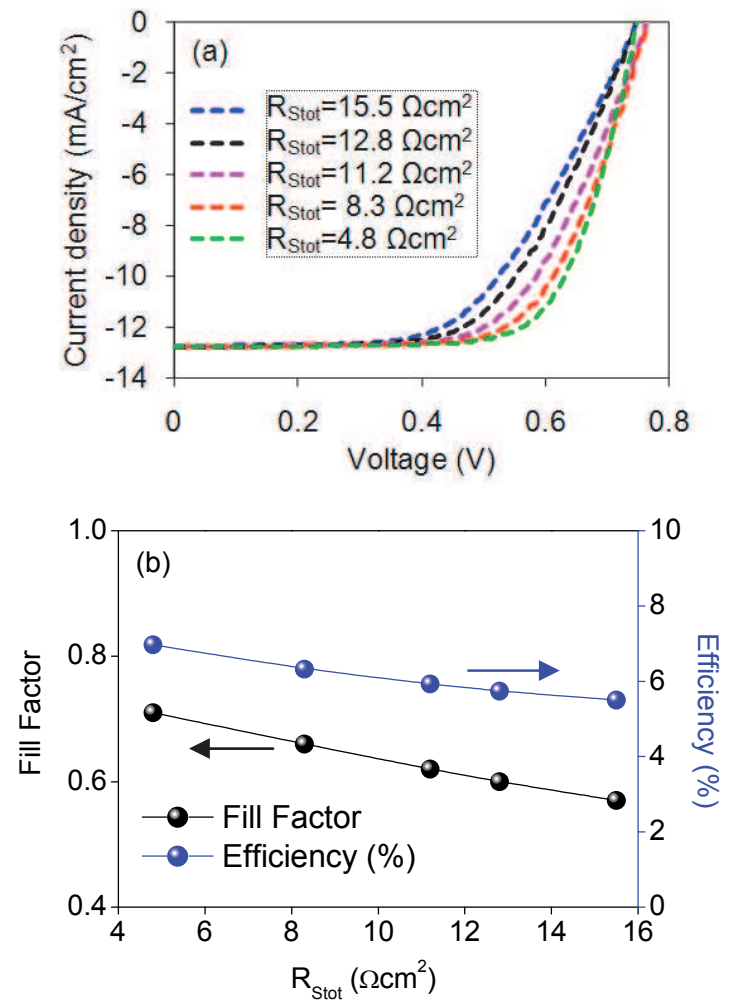

Fig. 8. (a) Simulated J-V curves of carbon nanofiber DSSCs with $R_{\text {Stot }}$ at $15.5 \Omega \mathrm{cm}^{2}$ (blue), $12.8 \Omega \mathrm{cm}^{2}$ (dark), $11.2 \Omega \mathrm{cm}^{2}$ (purple), $8.3 \Omega \mathrm{cm}^{2}$ (red), $4.8 \Omega \mathrm{cm}^{2}$ (green); (b) Relationship between FF (black), $\eta$ (blue) and $R_{\text {stot }}$. Reprinted with permission from \{Joshi et al. 2010\}. Copyright $\{2010\}$ American Chemical Society.

The larger internal series resistance was consistent with the higher $R_{s}$ in carbon nanofiber counter electrode, which was more than twice of that of $\mathrm{Pt}$ electrode obtained in symmetrical cells via EIS measurements. Second, carbon nanofiber counter electrode may have a higher $Z_{W}$ of triiodide ions than $\mathrm{Pt}$ electrode because the thicker porous carbon nanofiber film increased the diffusion length of triiodide ions. This can also lead to a larger internal series resistance (Lee et al. 2009). A higher $Z_{W}$ was also reported previously in other nanostructured counter electrodes including surface-nitrided nickel (Jiang et al. 2010), 
carbon nanotubes (Lee et al. 2009; Li et al. 2010), and carbon nanoparticles (Murakami et al. 2006). A series of J-V curves at different $R_{\text {stot }}$ were simulated in order to quantitatively study the $R_{\text {Stot }}$ effects on carbon nanofiber counter electrode DSSC performance. The dependence of FF and $\eta$ on $R_{\text {Stot }}$ in carbon nanofiber counter electrode is plotted in Figure $8 b$. When decreasing $R_{\text {Stot }}$ from 15.5 to $4.8 \Omega \mathrm{cm}^{2}$, FF and $\eta$ can be significantly improved and approach that of Pt DSSCs. A promising approach to decreasing $R_{\text {Stot }}$ is to reduce the thickness of carbon nanofiber counter electrode via a thinner and more porous carbon nanofiber sheet.

\section{Conclusion}

The carbon/ $\mathrm{TiO}_{2}$ composite and carbon nanofiber were used as low cost alternative to $\mathrm{Pt}$ counter electrode for DSSCs. Although the efficiencies of carbon/ $\mathrm{TiO}_{2}$ composite and carbon nanofiber DSSC devices were lower than that of Pt devices, some of the parameters including $\mathrm{J}_{\mathrm{sc}}, \mathrm{V}_{\mathrm{oc}}$ or $\mathrm{FF}$ are comparable. The carbon/ $\mathrm{TiO}_{2}$ composite and carbon nanofiber counter electrodes have shown potential as an efficient electrocatalyst with low charge transfer resistance $\left(\mathrm{R}_{\mathrm{ct}}\right)$ and large surface area for reduction of $\mathrm{I}_{3}^{-}$ions.

\section{Acknowledgment}

This work was mainly supported by NSF EPSCoR/PANS program (EPS-EPSCoR-0903804 with some shared materials from NSF CAREER (ECCS-0950731) and NASA EPSCoR (NNX09AP67A). This work was modified from the previous journal publicaions (Joshi et al. 2009; Joshi et al. 2010). The authors acknowledge Drs Hao Fong and Lifeng Zhang at the South Dakota School of Mines and Technologies to provide carbon nanofiber samples for DSSC applications. The authors are also grateful to Dr. Mahdi F. Baroughi for help in setting up the J-V and IPCE measurement systems in the Department of Electrical Engineering and Computer Science at the South Dakota State University.

\section{References}

Alibabaei, L., M. K. Wang, et al. (2010). "Application of $\mathrm{Cu}(\mathrm{II})$ and $\mathrm{Zn}$ (II) Coproporphyrins as Sensitizers for Thin Film Dye Sensitized Solar Cells." Energy \& Environmental Science 3(7): 956-961.

Burnside, S., S. Winkel, et al. (2000). "Deposition and Characterization of Screen-Printed Porous Multi-layer Thick Film Structures from Semiconducting and Conducting Nanomaterials for Use in Photovoltaic Devices." Journal of Materials Science Materials in Electronics 11(4): 355-362.

Calandra, P., G. Calogero, et al. (2010). "Metal Nanoparticles and Carbon-Based Nanostructures as Advanced Materials for Cathode Application in Dye-Sensitized Solar Cells." International Journal of Photoenergy 2010: 109495.

Fan, B. H., X. G. Mei, et al. (2008). "Conducting Polymer/Carbon Nanotube Composite as Counter Electrode of Dye-Sensitized Solar Cells." Applied Physics Letters 93(14).

Fang, X. M., T. L. Ma, et al. (2004). "Effect of the Thickness of the Pt Film Coated on a Counter Electrode on the Performance of a Dye-Sensitized Solar Cell." Journal of Electroanalytical Chemistry 570(2): 257-263. 
Gajjela, S. R., K. Ananthanarayanan, et al. (2010). "Synthesis of Mesoporous Titanium Dioxide by Soft Template Based Approach: Characterization and Application in Dye-Sensitized Solar Cells." Energy \& Environmental Science 3(6): 838-845.

Gratzel, M. (2000). "Perspectives for Dye-Sensitized Nanocrystalline Solar Cells." Progress in Photovoltaics: Research and Applications 8(1): 171-185.

Gratzel, M. (2003). "Dye-sensitized solar cells." Journal of Photochemistry and Photobiology CPhotochemistry Reviews 4(2): 145-153.

Han, H. W., U. Bach, et al. (2009). "A Design for Monolithic All-Solid-State Dye-Sensitized Solar Cells with a Platinized Carbon Counterelectrode." Applied Physics Letters 94(10).

Hauch, A. and A. Georg (2001). "Diffusion in the electrolyte and charge-transfer reaction at the platinum electrode in dye-sensitized solar cells." Electrochimica Acta 46(22): 3457-3466.

Hinsch, A., S. Behrens, et al. (2008). "Material Development for Dye Solar Modules: Results from an Integrated Approach." Progress in Photovoltaics: Research and Applications 16(6): 489-501.

Huang, S. Y., G. Schlichthorl, et al. (1997). "Charge Recombination in Dye-Sensitized Nanocrystalline TiO2 Solar Cells." Journal of Physical Chemistry B 101(14): 2576-2582.

Huang, Z., X. Liu, et al. (2007). "Application of Carbon Materials as Counter Electrodes of Dye-Sensitized Solar Cells." Electrochemistry Communications 9(4): 596-598.

Imoto, K., M. Suzuki, et al. (2003). "Activated carbon counter electrode for dye-sensitized solar cell." Electrochemistry 71(11): 944-946.

Imoto, K., K. Takahashi, et al. (2003). "High-performance carbon counter electrode for dyesensitized solar cells." Solar Energy Materials and Solar Cells 79(4): 459-469.

Jiang, Q. W., G. R. Li, et al. (2010). "Surface-Nitrided Nickel with Bifunctional Structure As Low-Cost Counter Electrode for Dye-Sensitized Solar Cells." The Journal of Physical Chemistry C 114(31): 13397-13401.

Joshi, P., Y. Xie, et al. (2009). "Dye-Sensitized Solar Cells based on Low Cost Nanoscale Carbon/TiO2 Composite Counter Electrode." Energy E Environmental Science 2(4): 426-429.

Joshi, P., L. Zhang, et al. (2010). "Electrospun Carbon Nanofibers as Low-Cost Counter Electrode for Dye-Sensitized Solar Cells." ACS Applied Materials \& Interfaces 2(12): 3572-3577.

Kay, A. and M. Gratzel (1996). "Low Cost Photovoltaic Modules Based on Dye Sensitized Nanocrystalline Titanium Dioxide and Carbon Powder." Solar Energy Materials and Solar Cells 44(1): 99-117.

Lee, W. J., E. Ramasamy, et al. (2009). "Efficient Dye-Sensitized Solar Cells with Catalytic Multiwall Carbon Nanotube Counter Electrodes." ACS Applied Materials E Interfaces 1(6): 1145-1149.

Li, G.-R., F. Wang, et al. (2010). "Carbon Nanotubes with Titanium Nitride as a Low-Cost Counter-Electrode Material for Dye-Sensitized Solar Cells13." Angewandte Chemie International Edition 49(21): 3653-3656.

Matsubara, T., R. Sakaguchi, et al. (2005). "Measurement and Analysis of the Series Resistance in a Dye Sensitized Solar Cells " Electrochemistry 73(1): 60 - 66.

Mei, X. and J. Ouyang (2009). "Gels of carbon nanotubes and a nonionic surfactant prepared by mechanical grinding." Carbon 48: 293-299. 
Murakami, T. N., S. Ito, et al. (2006). "Highly Efficient Dye-Sensitized Solar Cells based on Carbon Black Counter Electrodes." Journal of the Electrochemical Society 153(12): A2255-A2261.

Oregan, B. and M. Gratzel (1991). "A Low-Cost, High-Efficiency Solar-Cell Based on DyeSensitized Colloidal Tio2 Films." Nature 353(6346): 737-740.

Papageorgiou, N., W. F. Maier, et al. (1997). "An Iodine/Triiodide Reduction Electrocatalyst for Aqueous and Organic Media." Journal of The Electrochemical Society 144(3): 876-884.

Ramasamy, E., W. J. Lee, et al. (2007). "Nanocarbon counterelectrode for dye sensitized solar cells." Applied Physics Letters 90(17): 173103.

Skupien, K., P. Putyra, et al. (2009). "Catalytic Materials Manufactured by the Polyol Process for Monolithic Dye-sensitized Solar Cells." Progress in Photovoltaics: Research and Applications 17(1): 67-73.

Sun, H., Y. Luo, et al. "In Situ Preparation of a Flexible Polyaniline/Carbon Composite Counter Electrode and Its Application in Dye-Sensitized Solar Cells." The Journal of Physical Chemistry C 114(26): 11673-11679.

Sun, K., B. H. Fan, et al. (2010). "Nanostructured Platinum Films Deposited by Polyol Reduction of a Platinum Precursor and Their Application as Counter Electrode of Dye-Sensitized Solar Cells." Journal of Physical Chemistry C 114(9): 4237-4244.

Suzuki, K., M. Yamaguchi, et al. (2003). "Application of carbon nanotubes to counter electrodes of dye-sensitized solar cells." Chemistry Letters 32(1): 28-29.

Wang, M., A. M. Anghel, et al. (2009). "CoS Supersedes Pt as Efficient Electrocatalyst for Triiodide Reduction in Dye-Sensitized Solar Cells." Journal of the American Chemical Society 131(44): 15976-15977.

Xia, J., N. Masaki, et al. (2007). "Sputtered Nb2O5 as a Novel Blocking Layer at Conducting Glass/TiO2 Interfaces in Dye-Sensitized Ionic Liquid Solar Cells." The Journal of Physical Chemistry C 111(22): 8092-8097.

Mei, X., S. J. Cho, et al. (2010). "High-performance dye-sensitized solar cells with gel-coated binder-free carbon nanotube films as counter electrode." Nanotechnology 21(39): 395202.

Xie, Y., P. Joshi, et al. (2010). "Electrolyte Effects on Electron Transport and Recombination at ZnO Nanorods for Dye-Sensitized Solar Cells." The Journal of Physical Chemistry C 114(41): 17880-17888.

Xie, Y., P. Joshi, et al. (2009). "Structural effects of core-modified porphyrins in dyesensitized solar cells." Journal of Porphyrins and Phthalocyanines 13(8-9): 903-909.

Yum, J. H., E. Baranoff, et al. (2010). "Phosphorescent Energy Relay Dye for Improved Light Harvesting Response in Liquid Dye-Sensitized Solar Cells." Energy \& Environmental Science 3(4): 434-437. 


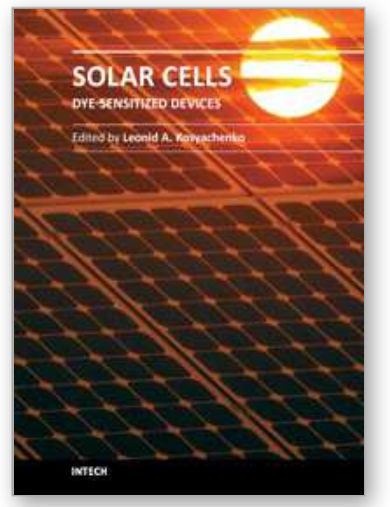

\author{
Solar Cells - Dye-Sensitized Devices \\ Edited by Prof. Leonid A. Kosyachenko
}

ISBN 978-953-307-735-2

Hard cover, 492 pages

Publisher InTech

Published online 09, November, 2011

Published in print edition November, 2011

The second book of the four-volume edition of "Solar cells" is devoted to dye-sensitized solar cells (DSSCs), which are considered to be extremely promising because they are made of low-cost materials with simple inexpensive manufacturing procedures and can be engineered into flexible sheets. DSSCs are emerged as a truly new class of energy conversion devices, which are representatives of the third generation solar technology. Mechanism of conversion of solar energy into electricity in these devices is quite peculiar. The achieved energy conversion efficiency in DSSCs is low, however, it has improved quickly in the last years. It is believed that DSSCs are still at the start of their development stage and will take a worthy place in the largescale production for the future.

\title{
How to reference
}

In order to correctly reference this scholarly work, feel free to copy and paste the following:

Qiquan Qiao (2011). Carbon Nanostructures as Low Cost Counter Electrode for Dye-Sensitized Solar Cells, Solar Cells - Dye-Sensitized Devices, Prof. Leonid A. Kosyachenko (Ed.), ISBN: 978-953-307-735-2, InTech, Available from: http://www.intechopen.com/books/solar-cells-dye-sensitized-devices/carbon-nanostructuresas-low-cost-counter-electrode-for-dye-sensitized-solar-cells

\section{INTECH}

open science | open minds

\section{InTech Europe}

University Campus STeP Ri

Slavka Krautzeka 83/A

51000 Rijeka, Croatia

Phone: +385 (51) 770447

Fax: +385 (51) 686166

www.intechopen.com

\section{InTech China}

Unit 405, Office Block, Hotel Equatorial Shanghai

No.65, Yan An Road (West), Shanghai, 200040, China

中国上海市延安西路65号上海国际贵都大饭店办公楼405单元

Phone: +86-21-62489820

Fax: +86-21-62489821 
(C) 2011 The Author(s). Licensee IntechOpen. This is an open access article distributed under the terms of the Creative Commons Attribution 3.0 License, which permits unrestricted use, distribution, and reproduction in any medium, provided the original work is properly cited. 